\title{
Additions to the bryophyte floras of Réunion and Mauritius (East African Islands)
}

\author{
Frank Müller \\ Institut für Botanik, Technische Universität Dresden, Mommsenstr. 13, D-01062 Dresden, \\ Germany
}

\begin{abstract}
Interesting records of bryophytes from the East African Islands Réunion and Mauritius are reported. Anomodon tristis (Ces.) Sull. \& Lesq. is reported with certainty for Africa. First records for the East African Islands of Calliergonella cuspidata (Hedw.) Loeske, Cephaloziella transvaalensis S. Arnell, Dicranella cardotii R. Br. ter., Hymenostylium recurvirostrum (Hedw.) Dixon, Pogonatum urnigerum (Hedw.) P. Beauv. and Scorpiurium circinatum (Brid.) M. Fleisch. \& Loeske are listed. Riccia cavernosa Hoffm. em. Raddi and Syrrhopodon parasiticus (Brid.) Besch. are reported as new for the Mascarenes and Brachymenium exile (Dozy \& Molk.) Bosch. \& Sande Lac. and Fossombronia foveolata Lindb. as new for Mauritius.
\end{abstract}

\section{Introduction}

In September and October 2000 the author made a second visit to the Mascarenes; the results of the first trip were reported in an earlier paper (Müller 2000). In 2000 the author collected on Réunion, Mauritius and Rodrigues. The results of the exploration of the very poorly known bryoflora of Rodrigues will be reported in a separate paper, which is in preparation. In the present paper some new records for the bryofloras of Réunion and Mauritius are reported. The bryophyte collection of the 2000 excursion is up to now only partly examined, so further studies will probably increase the number of interesting specimens.

\section{Annotated list of species}

The nomenclature of the species follows O'Shea (1999) for the mosses and Wigginton \& Grolle (1996) for the liverworts. Voucher specimens are in the author's personal herbarium. For specimens sent to specialists for determination or confirmation, duplicates exist in their personal herbaria. All species are reported for the first time for Réunion or Mauritius.

\section{Hepaticae}

Cephaloziella transvaalensis S. Arnell Mauritius: Black River Gorges National Park, c. $2 \mathrm{~km} \mathrm{NW}$ of le Petrin, c. $600 \mathrm{~m}$, sparse rainforest, 
earthy slopes along a path; 4.10.2000; herb. $F$. Müller $R 884$, det. J. V«×a.

First record for the East African Islands. In Africa the species was hitherto known only from the Republic of South Africa (Wigginton \& Grolle 1996) and Tanzania (Pócs 1994).

Fossombronia foveolata Lindb.

Mauritius: Black River Gorges National Park, c. $2 \mathrm{~km} \mathrm{NW}$ of le Petrin, c. $600 \mathrm{~m}$, earthy slopes along a path in a sparse rainforest; 4.10.2000; herb. F. Müller R 892, conf. S. Perold.

This species was recently reported as new for the East African Islands from the neighbouring island Réunion by Müller (2000). The species is probably more widely distributed in this area.

Riccia cavernosa Hoffm. em. Raddi

Réunion: Cilaos, les Trois Mares, c. 1200 m, on lake mud; 19.9.2000; herb.F. Müller R 912, conf. S. Perold.

In the East African Islands the species was hitherto only known from Madagascar (Grolle 1995). It is widely distributed in continental Africa (Wigginton \& Grolle 1996).

\section{Musci}

Anomodon tristis (Ces.) Sull. \& Lesq.

Réunion: Cilaos NW, along the hiking trail to the Col du Taibit in the area of Plaine des Fraises, c. $1800 \mathrm{~m}$, on boulders in sparse forest; 21.9.2000; herb. F. Müller R 728, conf. B.J. O'Shea.

First certain record for Africa. In Africa it was recorded only by Potier de la Varde, from two localities in Kenya (see O'Shea 2000), but no herbarium material was located for these collections. Therefore O'Shea (2000) concluded that it is most likely that the collections were misidentified and belonged to A. pseudotristis, and $A$. tristis was therefore excluded from the checklist of the mosses of sub-Saharan Africa (O'Shea 1999). In the revision of the genus by Granzow-de la Cerda (1997) it was also not mentioned as occurring in Africa.

Anomodon tristis shows a very scattered distribution. It is known from Europe (Switzerland, Italy, Austria, the former Yugoslavia, Romania), Asia (eastern China,
Japan, Taiwan, Himalayas, Russian Far East, Turkey), North, Central and South America, Hawaii (Düll 1985, Granzow-de la Cerda 1997, O'Shea in litt.).

Brachymenium exile (Dozy \& Molk.) Bosch. \& Sande Lac.

Mauritius: Black River Gorges National Park, c. $2 \mathrm{~km} \mathrm{NW}$ of le Petrin, c. $600 \mathrm{~m}$, earthy slopes along a path in rainforest; 4.10.2000; herb. $F$. Müller $R 892$.

This species was just reported as new for Réunion by Müller (2000) and can now also reported as new for Mauritius. In Réunion the species is widely distributed, and many additional records was made on this island during the excursion in 2000 by the author. In addition, it was found on Réunion in many places by the late T. Arts (Arts, in litt.).

Calliergonella cuspidata (Hedw.) Loeske Mauritius: Curepipe, in the Botanical Garden, c $500 \mathrm{~m}$, on wet soil in meadows; 2.10.2000; herb. F. Müller R 907.

This species was recently reported from Ethiopia as new for sub-Saharan Africa (Ignatov \& Pavlov 1998). The record in the Botanical Garden in Mauritius rests most likely on introduction. The species is widely distributed in the Northern Hemisphere and is known in the Southern Hemisphere from New Zealand, Australia and southern South America.

Dicranella cardotii R. Br. ter. (Anisothecium cardotii [R. Br. ter.] Ochyra)

Réunion: Cilaos NW, Col du Taibit, c. 2000 m, sparse mountainous rainforest, slope along a path; 21.9.2000; herb. F. Müller R $888 \&$ \& 889, conf. R. Ochyra.

In Africa this species was hitherto only known from the Republic of South Africa (O'Shea 1999). It can now reported as new for the East African Islands. The species shows a pan-southtemperate distribution and is known elsewhere from New Zealand, SE Australia, Tasmania, Campbell I., Subantarctica, Falkland Is., Tierra del Fuego, South and West Patagonia, Antarctica and Colombia (Ochyra 1998).

Hymenostylium recurvirostrum (Hedw.) Dixon 
Réunion: Cilaos NW, along the path to the Cascade du Bras Rouge, c. $1100 \mathrm{~m}$, on wet rocks near a brook; 17.9.2000; herb. F. Müller R 918. First record for the East African Islands.

Pogonatum urnigerum (Hedw.) P. Beauv.

Réunion: Cilaos, along the path from Coteau Kerveguen to the Foret de la Mare a Joseph, c. $1900 \mathrm{~m}$, slopes in mountainous rainforest; 18.9.2000, herb. F. Müller R 910.

First record for the East African Islands. In Africa the species is known from higher altitudes in East Africa and Cameroon (O’Shea 1999).

Scorpiurium circinatum (Brid.) M. Fleisch. \& Loeske

Mauritius: Curepipe, in the Botanical Garden, c. $500 \mathrm{~m}$, on a concrete wall of a bridge; 2.10.2000; herb. F. Müller R 883, conf. R. Ochyra.

First record for the East African Islands. In subSaharan Africa the species was hitherto only known from Cape Verde and Djibouti (O'Shea 1999). It is known elsewhere from western and southern Europe, northern Africa, Southwest Asia and Macaronesia (Düll 1985). The occurrence on Mauritius is well outside the hitherto known range and rests most likely on an introduction. At the same site Calliergonella cuspidata was also found, another probably introduced species (see above).

Syrrhopodon parasiticus (Brid.) Besch.

Réunion: St-Philippe N, Sentier du Plle Tremblet a little below Abri du Tremblet, c. 1000 m, mountain rainforest, on thin branches of trees; 23.9.2000; herb. F. Müller R 906.

First record for the Mascarenes. In Africa the species is known elsewhere from Cameroon, Madagascar and Uganda (O'Shea 1999). The species shows a pantropical distribution. The record on Réunion was made in an area with very high annual rainfall.

\section{Acknowledgements}

For confirmation or determination of material I wish to thank the following persons: R. Ochyra (Cracow) Dicranella cardotii, Scorpiurium circinatum, S. Perold (Pretoria) - Fossombronia foveolata, Riccia cavernosa, B.J. O'Shea (London) - Anomodon tristis, J. Vana (Prague) - Cephaloziella transvaalensis. I am especially grateful to Mr. B.J. O'Shea (London) for correcting the English text and helpful comments.

\section{References}

Düll, R. 1985. Distribution of the European and Macaronesian Mosses. - Bryologische Beiträge 5: 108-232.

Granzow-de la Cerda, I. 1997. Revision and phylogeny of Anomodon and Herpetineuron (Anomodontaceae, Musci). - Contributions from the University of Michigan Herbarium 21: 205-275

Grolle, R. 1995. The Hepaticae and Anthocerotae of the East African Islands. An Annotated Catalogue. - Bryophytorum Bibliotheca 48: 1-178.

Ignatov, M.S. \& Pavlov, V.N. 1998. Calliergonella cuspidata (Hedw.) Loeske (Musci) - a new genus for tropical Africa. - Arctoa 7: 81-82.

Müller, F. 2000. Additions to the bryophyte flora of Réunion (East African Islands). - Tropical Bryology 18: 91-95.

Ochyra, R. 1998. The Moss Flora of King George Island, Antarctica. - Cracow: Polish Academy of Sciences, W. Szafer Institute of Botany.

O'Shea, B.J. 1999. Checklist of the mosses of subSaharan Africa (version 3, 11/99). -Tropical Bryology Research Reports 1: 1-133.

O'Shea, B.J. 2000. Taxonomic notes on Anomodon (Anomodontaceae, Bryopsida) in Africa. Journal of Bryology 22: 241-242.

Pócs, T. 1994. The altitudinal distribution of Kilimanjaro bryophytes. - In: J.H. Seyani \& A.C. Chikuni, Proceedings of the $13^{\text {th }}$ Plenary Meeting, AETFAT, Malawi, 2: 797812.

Wigginton, M.J. \& Grolle, R. 1996. Catalogue of the Hepaticae and Anthocerotae of SubSaharan Africa. - Bryophytorum Bibliotheca 50: 1-267. 
